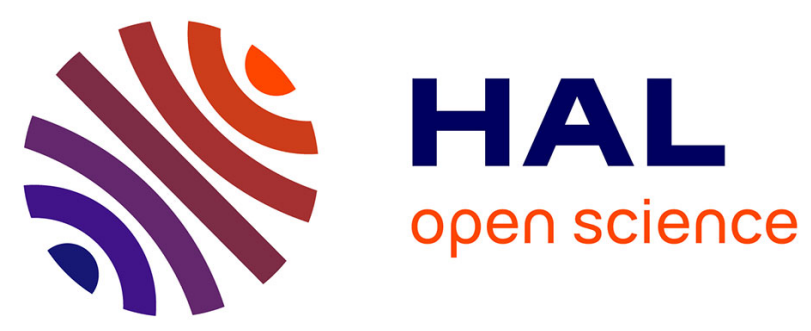

\title{
HOW ADULT ENGLISH LEARNERS OF FRENCH EXPRESS CAUSED MOTION: A COMPARISON WITH ENGLISH AND FRENCH NATIVES
}

Henriëtte Hendriks, Maya Hickmann, Annie-Claude Demagny

\section{- To cite this version:}

Henriëtte Hendriks, Maya Hickmann, Annie-Claude Demagny. HOW ADULT ENGLISH LEARNERS OF FRENCH EXPRESS CAUSED MOTION: A COMPARISON WITH ENGLISH AND FRENCH NATIVES. Acquisition et Interaction en Langue Etrangère, 2008, Savoirs et savoir-faire dans l'apprentissage et l'enseignement d'une langue étrangère, 27, http://aile.revues.org/2243. halshs01144888

\author{
HAL Id: halshs-01144888 \\ https://shs.hal.science/halshs-01144888
}

Submitted on 21 Jun 2015

HAL is a multi-disciplinary open access archive for the deposit and dissemination of scientific research documents, whether they are published or not. The documents may come from teaching and research institutions in France or abroad, or from public or private research centers.
L'archive ouverte pluridisciplinaire HAL, est destinée au dépôt et à la diffusion de documents scientifiques de niveau recherche, publiés ou non, émanant des établissements d'enseignement et de recherche français ou étrangers, des laboratoires publics ou privés. 


\title{
Acquisition et interaction en langue étrangère
}

27 (2008)

Savoirs et savoir-faire dans l'apprentissage et l'enseignement d'une langue étrangère

Henriette Hendriks, Maya Hickmann et Annie-Claude Demagny

\section{How adult English learners of French express caused motion: A comparison with English and French natives}

\author{
Avertissement \\ Le contenu de ce site relève de la législation française sur la propriété intellectuelle et est la propriété exclusive de \\ l'éditeur. \\ Les œuvres figurant sur ce site peuvent être consultées et reproduites sur un support papier ou numérique sous \\ réserve qu'elles soient strictement réservées à un usage soit personnel, soit scientifique ou pédagogique excluant \\ toute exploitation commerciale. La reproduction devra obligatoirement mentionner l'éditeur, le nom de la revue, \\ l'auteur et la référence du document. \\ Toute autre reproduction est interdite sauf accord préalable de l'éditeur, en dehors des cas prévus par la législation \\ en vigueur en France.
}

\section{revues.org}

Revues.org est un portail de revues en sciences humaines et sociales développé par le Cléo, Centre pour l'édition électronique ouverte (CNRS, EHESS, UP, UAPV).

\author{
Référence électronique \\ Éditeur : Association Encrages \\ http://aile.revues.org \\ http://www.revues.org \\ Document accessible en ligne sur : http://aile.revues.org/3973 \\ Ce document est le fac-similé de l'édition papier. \\ (c) Tous droits réservés
}

Henriette Hendriks, Maya Hickmann et Annie-Claude Demagny, « How adult English learners of French express caused motion: A comparison with English and French natives », Acquisition et interaction en langue étrangère [En ligne], 27 | 2008, mis en ligne le 30 septembre 2011, consulté le 10 octobre 2012. URL : http://aile.revues.org/3973 


\title{
HOW ADULT ENGLISH LEARNERS OF FRENCH EXPRESS CAUSED MOTION: A COMPARISON WITH ENGLISH AND FRENCH NATIVES
}

\author{
Henriette HENDRIKS \\ (University of Cambridge, RCEAL) \\ Maya HICKMANN \\ (Structures Formelles du Langage, CNRS \& University of Paris 8) \\ Annie-Claude DEMAGNY \\ (University of Paris 8)
}

\begin{abstract}
This study examines the impact of typological properties (satellite - vs. verbframed languages) on the expression of caused motion during adult second language acquisition. Productions were elicited by means of animated cartoons from 24 English learners of French (12 low-intermediate, 12 advanced) as compared to 24 native speakers (12 English, 12 French). The responses of native speakers differed with respect to semantic density (English $>$ French) and to the systematic (English) vs. variable (French) devices used. As for learners, their utterance density increased with proficiency level as they acquired complex structures. Source/target language properties influenced this process, as shown by their increasing attempt to produce target-like structures that nonetheless remained source-like at both proficiency levels. These typological constraints suggest that learners do not construct an entirely independent linguistic system during second language acquisition and that L2 mastery may require some reconceptualization of spatial information. The discussion indicates research directions that might explore the implications of these results for language teaching.
\end{abstract}

(Keywords : second language acquisition, typology, space, caused motion.)

\section{Introduction}

Research on second language acquisition has shown that multiple factors determine how learners acquire a new linguistic system. These factors include, 
for example, age of acquisition, type of acquisition (e.g. guided versus nonguided), age of arrival in the country where the second language is naturally spoken, and factors of transfer (from source language to target language). With respect to the last factor, debates concerning the role of typological properties on language acquisition have rekindled in the last twenty years. Although this question was first addressed in relation to first language acquisition (e.g. Gentner \& Goldin-Meadow, 2003 ; Gumperz \& Levinson, 1996 ; Hickmann \& Robert, 2006), it is now also central to studies on transfer during second language acquisition (e.g. Becker \& Carroll, 1997 ; Cadierno, 2004 ; Cadierno \& Lund, 2004 ; Carroll \& von Stutterheim, 2003 ; Carroll et al., 2000, 2008 ; Hendriks, 2005 ; von Stutterheim, 2003 ; von Stutterheim \& Lambert, 2005).

In the present paper we examine whether the typological properties of English (source language) and French (target language) have an impact on adult second language acquisition, particularly in the spatial domain. Since these two languages belong to two different families (Talmy, 1985, 2000), data concerning the acquisition of French by English learners should provide some insights in this respect. We first indicate why space is particularly informative in relation to these questions in light of English vs. French typological features and of previous studies on L1 and L2 acquisition in this domain. We then present results from a study comparing how adult English learners of French (at two proficiency levels) and native speakers (of French or English) described caused motion events. The discussion highlights the implications of the results for second language acquisition and suggests future research directions that could explore their implications for language teaching.

\section{Space and language : universals and typological differences}

When we talk about events, we must keep track of several types of information, including spatial dimensions defining where they take place. Consequently, all languages provide means of referring to motion and location. Given the importance of space in our lives, many researchers have hypothesized that some universal factors influence human cognition in this domain and that spatial language should closely mirror non-linguistic spatial concepts. However, many recent findings suggest that languages differ in fundamental ways (Bowerman, 1996 ; Brown, 2001 ; Levinson \& Wilkins, 2006 ; Nuyts \& Pederson, 1997). Among other differences, they display a different division of labour between different parts of speech. For example, in Indo-European languages, verbs tend to encode relations between entities, but do not specify 
much about the properties of these entities, which are encoded by nouns. In contrast, in the Mayan language Tzeltal (Brown, 2001) verbs encode properties of entities, while nouns (especially inanimate) are unspecified as to the forms of their referents.

According to Talmy $(1983,1985,2000)$, motion in language minimally involves several basic components : movement per se or the maintenance of a stationary location (MOTION) ; a moving or conceptually moveable entity (FIGURE); an object with respect to which the figure moves (GROUND); and the trajectory followed by the figure with respect to the ground (PATH). All languages further distinguish several types of motion events, such as those that do or do not imply a change of location (e.g. English into/in), and can express other types of information, such as the cause of motion and the manner in which it takes place. Talmy further characterizes languages in terms of several families depending on the particular lexical and grammatical means they provide to express these different informational components, particularly in the case of events that imply changes of location ( $c f$. also Aske, 1989 ; Slobin, 1997). A major distinction for the present study is the one between satellite-framed vs. verb-framed languages (hereafter $S$ - vs. V-languages, e.g. Germanic vs. Romance, respectively). In S-languages MOTION is conflated with CAUSE and/or MANNER in the verb, while PATH is expressed in satellites, e.g. in English (1) and (2) ${ }^{1}$.

(1) a. She is walking [MANNER] in [LOCATION] the house. (- change of location)

b. She is walking [MANNER] into [РATH] the house. (+ change of location)

c. She is walking [MANNER] across [PATH] the road. (+ change of location)

(2) a. She is rolling [CAUSE+MANNER] the ball into [РATH] the house. (Caused motion)

b. She is rolling [CAUSE+MANNER] the ball up [PATH] the hill. (Caused motion)

V-languages present a very different pattern. With voluntary motion events, MOTION is conflated with MANNER when there is no change of location (cf. (3a) which is similar to English (1a)). However, with location changes MOTION is conflated with PATH in the verb, while MANNER is expressed (if at all) by peripheral means such as gerunds or adverbial constructions, e.g. French (3b) and $(3 \mathrm{c})$.

1. These typological features characterize the most prototypical patterns of each language, but do not exclude other co-existing structures within a given system, e.g. English path verbs (such as to leave and to enter) or French manner verbs with goal expressions as in Elle a couru à l'école 'She ran to school'). 
(3) a. Elle marche [MANNER] dans la maison. (- change of location) 'She is walking in the house.'

b. Elle entre [РАTH] dans la maison en courant [MANNER] (+ change of location) 'Lit.: She is entering in the house by running.'

c. Elle traverse [PATH] la route à pied [MANNER]. (+ change of location) 'Lit.: She is crossing the road on foot.'

As for caused motion, it is typically expressed in one of two ways : either by means of complex causative constructions (faire 'make' + infinitive) as in (4) or by means of transitive verbs as in (5). In principle, MOTION and CAUSE may be conflated with PATH or with MANNER (but not with both), although uses of both construction types are much more restricted than in English. For example, conflation with MANNER is more restricted pragmatically (to contexts where manner is particularly relevant) and formally (more limited to the first construction, e.g. faire glisser 'to make slide') ${ }^{2}$.

(4) a. Le jeu consiste à faire glisser [CAUSE+MANNER] des palets sur une planche.

'The game consists of sliding [Lit. 'of making slide'] disks on a board.'

b. Le jeu consiste à faire entrer [CAUSE+PATH] les billes dans les trous.

'The game consists of making the marbles go into the holes.' [Lit. 'of making enter']

(5) a. Quelqu'un va vous aider à monter/descendre la valise.

'Someone will help you take the suitcase up/down.' [Lit. 'to ascend/descend the suitcase']

b. S'il pleut, il faudra rentrer [CAUSE+PATH] les chaises.

'If it rains, we'll have to bring the chairs in.' [Lit. 'to enter the chairs']

As shown in detail below, recent cross-linguistic research (Bowerman \& Choi, 2003 ; Choi \& Bowerman, 1991 ; Hickmann, 2007 ; Hickmann \& Hendriks, 2005 ; Slobin, 1996) has begun to examine the implications of these typological differences for first language acquisition. Findings show important

2. Uses of French causative constructions depend on many variables, such as the nature of the displaced object, of the ground, of the action implicitly carried out by the agent, and of the discourse that may or may not motivate the expression of manner. Some direct equivalents of English (1) and (2) may therefore seem odd in isolation. In the context of our study, native speakers appropriately produced the first type of construction (see examples below, e.g. Il fait rouler le ballon ('He rolls the ball'), but practically never the second type. Finally, note that passive constructions provide yet another way to express caused motion in both languages (rarely used in our study and therefore not discussed here). 
differences in how V- or S-speakers select and organize spatial information. Furthermore, developmental studies show that these differences can be observed in the productions of very young children and even in (pre-linguistic) infants' early comprehension. These results have raised more general questions concerning the cognitive impact of linguistic organization, which can be summarized by two main approaches to the relation between human language and cognition.

According to the most predominant view, language-specific differences are only superficial and do not affect our underlying spatial representations beyond language use (Clark, 2003 ; Landau \& Lakusta, 2006 ; Munnich \& Landau, 2003). Recently, however, some researchers have proposed that language structures deeply affect how we perceive and categorize spatial information. For example, Slobin $(1996,2003)$ proposes that some of our thinking is intimately tied to language, particularly the thinking we carry out online during the process of communicating (speaking, writing, signing, listening). According to this hypothesis, our "thinking for speaking" involves selecting those characteristics of the world that best fit the event conceptualization that is most readily encoded in our language. Furthermore, L1 acquisition would imply that children acquire not only a language, but also a particular way of thinking about the world. With respect to L2 acquisition, learners may find it difficult to adjust to a typologically different system of organizing spatial information.

\section{Previous studies on $L 1$ and $L 2$ acquisition}

Relevant studies of child L1 acquisition have put forth two hypotheses. According to one proposal, early spatial concepts follow universal principles of organization that are independent of language(s) and are either built into our biological inheritance (Spelke, 1998) or learnt very rapidly (Mandler, 1998). A second hypothesis postulates that language has an impact on children's spatial concepts from the earliest age onward. Within the latter approach, experiments indeed show that infants' linguistic environment (English $v s$. Korean) influences how they categorize motion events during the pre-linguistic period (Bowerman \& Choi, 2003) and talk about them in their early productions (Choi \& Bowerman, 1991). Some of our research on the expression of voluntary motion (Hickmann, 2003, 2006) shows that English-speaking adults and children (ages three to ten) systematically express MANNER+PATH. In contrast, French speakers do so less frequently (adults) or rarely (children), frequently focusing on PATH 
alone (at all ages), except when appropriate path verbs are not available to children (focus on manner). Similarly, with respect to caused motion (Hickmann \& Hendriks, 2006), utterance density (the number of expressed information components) is higher in English than in French at all ages and increases drastically after 6-7 years in French (but not in English).

Researchers in second language acquisition have examined the extent to which L1 spatial systems have an influence on how learners acquire L2 spatial systems. In this respect, L2 acquisition provides further evidence to address the question of the relation between language and cognition. If our language only has a superficial impact on behaviour that does not go beyond speech, then it should be relatively easy for learners to adjust to a new spatial system. In contrast, if language has a deeper impact on our underlying representations, then it should be relatively difficult for learners to acquire a new way of categorizing spatial information in a second language.

Available studies in the spatial domain mainly concern static spatial expressions (cf. Becker \& Carroll, 1997 ; Carroll et al., 2000). They show that adults and children - learning L2 and L1 languages respectively - follow the same developmental progression (e.g. topological $>$ axis-based relations), despite their differing levels of cognitive maturity. Although few studies concern motion events (Cadierno, 2004 ; Cadierno \& Lund, 2004), some recent findings show that typological differences partially influence how L2 learners initially express motion in narratives. In particular, Danish learners of Spanish express PATH in multiple ways (using several PATH expressions, as in their source language), but fail to express all of this information within the sentence, as would be necessary in their target language (lack of event conflation). In addition, few L2 studies have examined the level of linguistic organization that may be affected by language-specific properties beyond the utterance level. Exceptions (Carroll et al., 2000) show that, although near-native L2 learners can produce error-free spatial expressions, the ways in which they organize spatial information in discourse is non-native like. Carroll et al. propose that these speakers' problems may lie in the cognitive cost implied by finding the appropriate expressions when using them in a more complex verbal task.

In this context, the present study addresses two general questions. First, as they map the semantics of motion onto L2 surface forms, do the typological properties of learners' source/target languages influence how they construct an interlanguage? Second, how do learners evolve with increasing proficiency? If a typological effect is observed, how do learners overcome the influence of their L1 during L2 acquisition ? In order to address these questions, we 
compared how English learners of French (at two proficiency levels) and native speakers of English and French (S- and V-languages, respectively) described caused motion events that simultaneously displayed multiple types of information. As described in more detail below, it was predicted that responses should differ as a function of language and of proficiency level, particularly with respect to three related dimensions : the quantity of information included in responses (semantic density), the type of information expressed (focus), and the linguistic means used to encode information (locus).

\section{Methodology}

\subsection{Subjects}

We analyze below the productions of 48 adult speakers divided into four groups (12 per group, males and females) : two groups of native speakers (French- and English-speaking) and two groups of English learners of French (at a low-intermediate or more advanced level of proficiency). All native speakers were students at the Universities of Paris and of Cambridge. All learners were students at the American University of Paris. Their proficiency level was based on an independent placement test administered by the American University of Paris upon arrival, which determined their class level ${ }^{3}$. An additional sociolinguistic questionnaire, including a self-evaluation, was developed and administered in the context of the project. Age of acquisition and age of arrival were kept constant within each of the two groups. All learners were around 20 years of age. Low-intermediate learners had recently arrived in Paris (one month), while advanced learners had all been there for approximately one year. All learners had had French at school for three to four years. All subjects were monolingual English speakers before they were exposed to French, with the exception of two subjects who were bilingual (EnglishSpanish, English-Arabic).

3. The test was the French Placement Exam of the American University of Paris. Most native speakers were students speaking British English ; some spoke American, Canadian, or Australian English. L2 learners were all American. We thank Rebekah Rast and Dominique Mougel for facilitating access to learners and to background information concerning them, as well as all participants from the American University of Paris. 


\subsection{Procedure}

Subjects were seen individually in their university setting. They were shown animated cartoons and asked to tell what had happened in each. In order to invite them to be as complete as possible, they described the cartoons for a fictitious listener who would not have seen the stimuli and would have to describe the cartoons only on the basis of the recordings. As shown in detail below, all subjects described the same set of items (40) during a session that lasted about 30 minutes, which included test items (32) and distractor items (7), presented in six different orders to which subjects were randomly assigned, as well as one initial training item that had all the characteristics of the test items.

\subsection{Materials}

A total of 32 test items were designed (see Appendix). They consisted of short animated cartoons in colour, all of which showed the same human agent in motion (called Popi in French and Hopi in English, hereafter A) carrying out an action that caused the displacement of an object (hereafter O). Table 1 summarizes the relevant informational components, two of which were constant across all items (A and B), while others systematically varied across items (C to $\mathrm{E}$ ). The crossing of variables $\mathrm{C}$ to $\mathrm{E}$ resulted in 16 possible combinations (2 $\mathrm{x} 2 \mathrm{x} 4$ ), each of which was presented by two exemplars (resulting in a total of 32 items). The $\mathrm{O}$ figures changed across the 16 combinations, while sceneries and ground referents varied across pairs of exemplars within each combination.

Table 1. Summary of main variables in test items

\begin{tabular}{|c|l|l|l|}
\hline A. & MANNER OF A-MOTION & Manner in which A moved & walking in all items \\
\hline B. & CAUSE & Causal relation between A and O & all items \\
\hline C. & MANNER OF CAUSE & Action of A causing O to move & PUSH, PULL \\
\hline D. & MANNER OF O-MOTION & Manner in which O moved & ROLL, SLIDE \\
\hline E. & PATH & Trajectory followed by A and O & $\begin{array}{l}\text { UP, DOWN, ACROSS, } \\
\text { INTO }\end{array}$ \\
\hline
\end{tabular}

A set of seven distractor items was meant to show subjects different types of situations (entities, sceneries, motion events, results) in order for them not to always expect the same type of information during the session. All showed an inanimate force (always a ball) causing inanimate entities to move (e.g. a ball 
rolling into a pile of dice, causing them to fall over) and in some cases causing an additional result (e.g. a ball rolling into a vase, causing it to fall over and to break). Regardless of the order in which test items were presented (orders 1 to 6), distractor items were interspersed at regular intervals among test items (a distractor occurred after every block of four test items).

Finally, the session began for all subjects with a training item (in which the agent moved a ball of hay across a road), which was meant to ensure that they would be comfortable with the task and to show them that multiple types of information were relevant. Subjects were prompted to provide the three different types of information that were systematically varied (variables $\mathrm{C}$ to $\mathrm{E}$ in Table 1 above) : the agent's action (MANNER OF CAUSE), the manner of the object's motion (O-MANNER OF MOTION), and the path followed by the agent and patient (PATH). Example (6) illustrates this training with a native English speaker. The experimenter's question elicits the MANNER OF O'S MOTION (roll) that was missing from the subject's initial description (CAUSE, MANNER OF CAUSE, and PATH in push across) ${ }^{4}$.

(6) ${ }^{5}$ SUB : Hopi pushes the bail of hay across the street.

EXP : And what about the ball?

SUB : It rolls as it went to the other side. (EAD02)

\subsection{Coding}

All sessions were entirely transcribed. Analyses focus only on responses that were elicited with test items, that is 32 responses per subject (thus a total of 384 responses per group). Coding aimed at providing three related measures of each response in order to examine subjects' productions from different angles : 1) overall semantic density, which corresponded to the total number of

4. A standardized questioning procedure privileged general questions during the training item. All questions were avoided after this initial item.

5. In all examples from our corpus, codes in parentheses identify subject groups (E and $\mathrm{F}=$ English and French natives, LOW-INT and ADV $=$ low-intermediate and advanced learners). The sign \# indicates pauses. Translations attempt to render the original French structure (sometimes awkward in English). Phonetically ambiguous forms are indicated whenever they could not be resolved on the basis of context and concern French verbs ending in /E/ (e.g., /poussE/ 'to push' or 'pushed') when used without auxiliaries (necessary for the perfective past, Il $l$ 'a poussé 'he [has] pushed it'), which are either infinitival (pousser 'to push') or past participial (poussé 'pushed'). 
elements expressed (among variables A to $\mathrm{E}$ in Table 1 above) and resulted in three groups (one, two, three or more, hereafter SD1, SD2, SD3+) ; 2) information focus, i.e. what was expressed ; 3) information locus, i.e. the particular linguistic devices used to express this information (main verbs $v s$. other devices). The responses below contain (in bold and square brackets) one component in (7) (PATH in main verb), two components in (8) and (9) (CAUSE + A-MANNER or O-MANNER in main verbs), and three components in (10) and (11) (CAUSE+O-MANNER in main verb, PATH in other devices) ${ }^{6}$.

(7) Maintenant Popi est descendu [PATH] 1(e) montagne avec une \# ballon. (LOWINT01)

'Now Popi has come down the mountain with a balloon.'

(8) Papy pousser/poussé [CAUSE+A-MANNER] une roue dans une caverné dans les bois. (LOW-INT01)

'Popi to push/pushed a tire into the cave in the woods.'

(9) Popi a fait rouler [CAUSE + O-MANNER] une grosse roue noire \# dans la forêt. (F20)

'Popi made a big black tire roll \# in the forest.'

(10) Hopi rolled [CAUSE + O-MANNER] the wheelbarrow down [PATH] the hill. (E02)

(11) Hopi le roule [CAUSE + O-MANNER] en descendant [PATH] la colline. (ADV03)

'Hopi rolls it descending the hill.'

\subsection{Predictions}

The results are presented below in terms of the three measures that were developed for the analyses (density, focus, locus). On the basis of the typological properties of English $v s$. French (S- and V-languages), the following predictions were made. First, it was predicted that native speakers should express more information in English than in French (density), particularly because they should express MANNER information more frequently (focus), as

6. The density measure depended partly on the architecture of the responses, which corresponded to a fourth measure (not presented here). Coordinated clauses were coded as containing more than one competing target (e.g. (a) Hopi pulls a heavy bag behind him and goes up the roof), whereas a sentence with subordination was coded as one target (e.g. (b) Hopi goes up the roof pulling a heavy bag behind him). In cases such as (a) the richest clause was systematically selected (most semantic components within a single sentence, i.e. pull). As a result, semantic density was lower in (a) cases than in (b) cases. 
a result of the linguistic devices available in their system (locus). English natives should use compact structures conflating CAUSE+MANNER in main verbs and expressing PATH in satellites (e.g. to push/roll the ball up). French speakers should express PATH or PATH+CAUSE in main verbs (either separately or conflated) and they should either not express MANNER at all (e.g. monter le ballon 'to ascend the ball') or express this information with peripheral means (monter la colline en poussant le ballon 'to ascend the hill pushing the ball').

Second, with respect to learners, it was predicted that their productions in French L2 should show some transfer from English L1, particularly at the low-intermediate level. At this level they should use main verbs to express CAUSE+MANNER and consequently confront some difficulties in expressing PATH. With increasing proficiency in L2, they should acquire a more native-like pattern, at least at the sentence level, using a CAUSE+PATH verb and adding MANNER information in various ways, including by means of more complex structures involving subordination.

\section{Results}

\subsection{Utterance density}

Overall semantic density within each group was defined as the percentage of responses that fell into each of the three density categories (SD1, $\mathrm{SD} 2, \mathrm{SD} 3+$ ) calculated over the total number of responses per group (384). As expected, native speakers' utterances were denser in English than in French. English speakers used mostly utterances containing three or more information components $(92 \%)$. French speakers used such utterances to a lesser extent $(75 \%)$ and more utterances of lower density (SD1 and SD2 : 25\%). As for learners, they produced utterances of lower density than either English or French native speakers, irrespective of proficiency level. Low-intermediate learners mostly produced SD2 utterances $(78 \%)$ and rarely higher density utterances (12\%). Advanced learners produced some SD2 utterances (37\%), but also SD3+ utterances (53\%). In order to further interpret these results, we turn to the particular types of information that were expressed. 
Figure 1. Overall utterance density
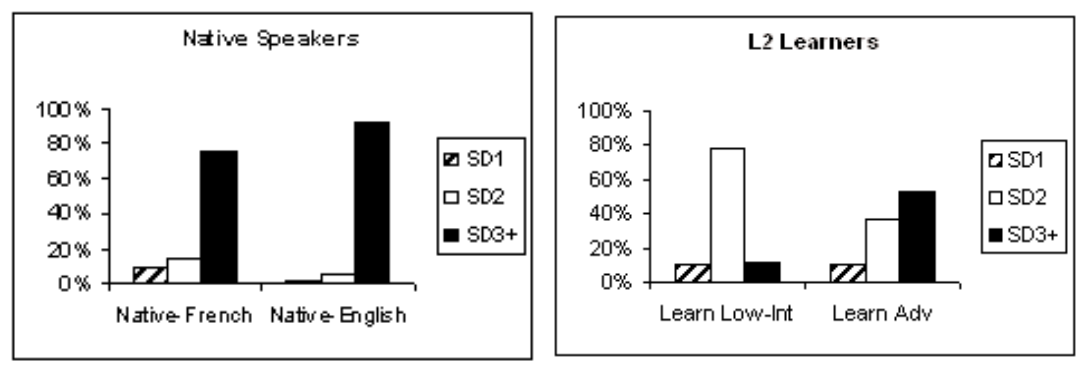

\subsection{Focus of information}

Information focus for each group corresponded to the percentage of responses that expressed each of the following three information components over the total number of responses per group (384) : 1) CAUSE (relation between agent and object) ; 2) MANNER (manner of A's action and manner of O' motion) ; 3) РATH (of A and O) ${ }^{7}$. Native speakers systematically expressed all three types of information in English (CAUSE 95\%, PATH 97\%, MANNER 97\%) and in French (CAUSE 89\%, PATH 85\%, MANNER 87\%). Contrary to expectations, no important differences occurred across languages with respect to what information was expressed overall. In contrast, both groups of learners expressed CAUSE and MANNER most often (low-intermediate CAUSE 90\%, MANNER $86 \%$; advanced CAUSE $93 \%$, MANNER $86 \%$ ), but they expressed PATH less often than native speakers (low-intermediate $21 \%$, advanced 63\%). Learners' less systematic expression of РATH may be surprising in light of the fact that this dimension of motion is most basic. We return to this point below. So far the data suggest that learners go from less explicit event descriptions to more complete ones.

7. Percentages of responses expressing each information type are calculated regardless of whether any other information was expressed together with it, e.g. the response Il monte en tirant la voiture 'He ascends pulling the car' was included three times for PATH, CAUSE, and MANNER OF CAUSE (therefore totals do not add up to $100 \%$ ). 
Figure 2. Types of information expressed in subjects' responses
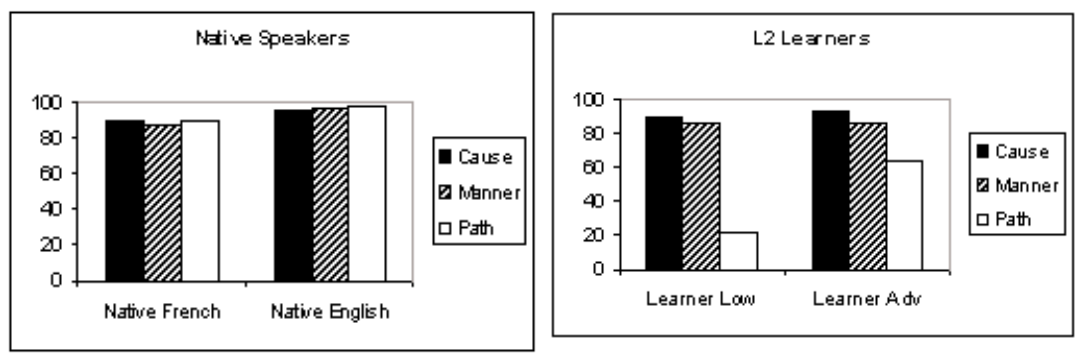

\subsection{Locus of information}

Information locus within each group was defined as the percentage of main verbs and of other devices (particles, prepositional/adverbial phrases, subordinate clauses) expressing some or no information (CAUSE, PATH, MANNER) over the total number of responses (384 per group). As shown in Figure 3, English speakers systematically expressed CAUSE+MANNER in main verbs $(93 \%)$ and PATH in other devices (94\%) ( $c f$. (12)). In contrast, French speakers produced a wide variety of structures, illustrated in (13) (same subject). Although main PATH verbs and other CAUSE+MANNER devices were most frequent (13a), many other structures occurred ((13b) to (13d)).

Figure 3. Distribution of information in main verbs $v$ s. other devices : native speakers
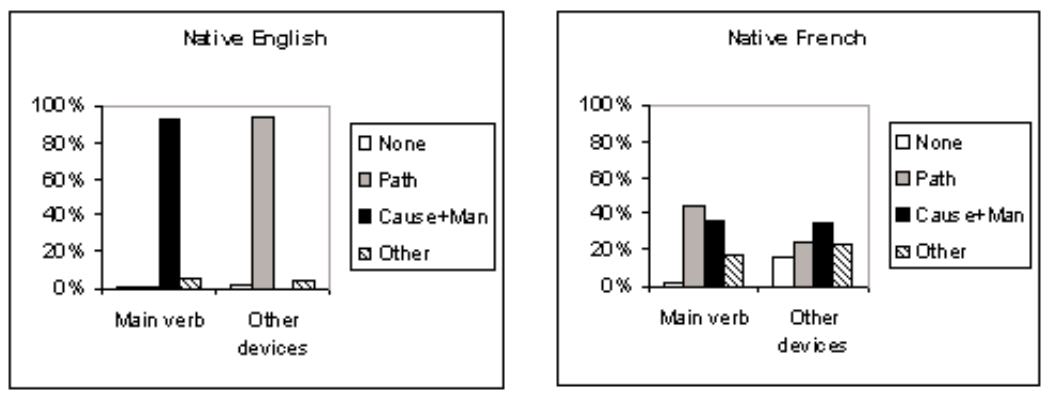
(12) Hopi pushed the suitcase down the hill. (E02)

(13) a. Popi descend la colline en faisant rouler le ballon jusqu'en bas. (F02)

'Popi goes down the hill making the ball roll all the way to the bottom.'

b. Il a tiré le sac très lourd tout en haut du toit. (F02)

'He pulled the very heavy bag all the way to the top of the roof.'

c. Alors Popi pousse la table pour la rentrer dans la maison. (F02)

'So Popi pushes the table to make it enter in[to] the house.'

c. Popi a fait rouler le gros pneu pour le rentrer dans le garage. (F02)

'Popi made the big tire roll in order to enter it into the garage.'

Although these results generally held for responses to all item types (see Appendix 1), more variation could be observed again among French speakers. In particular, the semantics of main verbs varied as a function of path in the presented items. Table 2 shows the percentages of responses that contained main verbs expressing each information type (MANNER OF MOTION, CAUSE, CAUSE OF MOTION, PATH) as a function of path in the presented items (INTO, ACROSS, UP, DOWN) (see Note 7).

Table 2. Semantic information expressed in the main verb as a function of path in the items

\begin{tabular}{|l|l|l|l|l|l|}
\hline & & $\begin{array}{l}\text { INTO } \\
\text { items }\end{array}$ & $\begin{array}{l}\text { ACROSS } \\
\text { items }\end{array}$ & $\begin{array}{l}\text { UP } \\
\text { items }\end{array}$ & $\begin{array}{l}\text { DOWN } \\
\text { items }\end{array}$ \\
\hline French & Manner of motion & $10 \%$ & $10 \%$ & $20 \%$ & $10 \%$ \\
\hline & Cause & $80 \%$ & $40 \%$ & $60 \%$ & $50 \%$ \\
\hline & Manner of cause & $50 \%$ & $20 \%$ & $30 \%$ & $30 \%$ \\
\hline \multirow{2}{*}{ English } & Path & $20 \%$ & $60 \%$ & $50 \%$ & $50 \%$ \\
\hline & Cause & $10 \%$ & $10 \%$ & $10 \%$ & $20 \%$ \\
\hline & Manner of cause & $80 \%$ & $80 \%$ & $80 \%$ & $80 \%$ \\
\hline & Path & 0 & $<1 \%$ & 0 & $<1 \%$ \\
\hline
\end{tabular}

In descriptions of INTO items French verbs expressed CAUSE (e.g. amener 'to bring') and/or MANNER OF CAUSE (e.g. pousser 'to push') most frequently, but PATH least frequently (e.g. entrer 'to enter'). These descriptions combined CAUSE and/or MANNER OF CAUSE in main verbs with different types of information within the clause as in (14a) or across clauses as in (14b) (also see Note 6). With items presenting other paths, responses were more varied. The most 
frequent structure contained a main PATH verb with additional peripheral information (14c), but other patterns involved PATH in the periphery (14d). These results are partially in line with our predictions, according to which PATH was expected in French main verbs, with two notable exceptions : responses to INTO items did not follow this pattern and there was generally an unexpectedly great variability in French.

(14) a. Il pousse le pneu jusqu'à l'intérieur de la grotte. (F06)

'He pushes the tire up to the inside of the cave.'

b. Il pousse le pneu et il entre dans la grotte. (F03)

'He pushes the tire and he enters in[to] the cave.'

c. Il traverse la route en poussant son panier de pommes. (F09)

'He crosses the street pushing his basket of apples.'

d. Popi tire un sac derrière lui en montant un toit. (F03)

'Popi pulls a bag behind him [while] ascending a roof.'

In comparison, Figure 4 shows information locus among learners. Like English native speakers, both groups of learners expressed CAUSE+MANNER in main verbs (low-intermediate $84 \%$, advanced $80 \%$ ).

\section{Figure 4. Distribution of information in main verbs} vs. other devices : learners
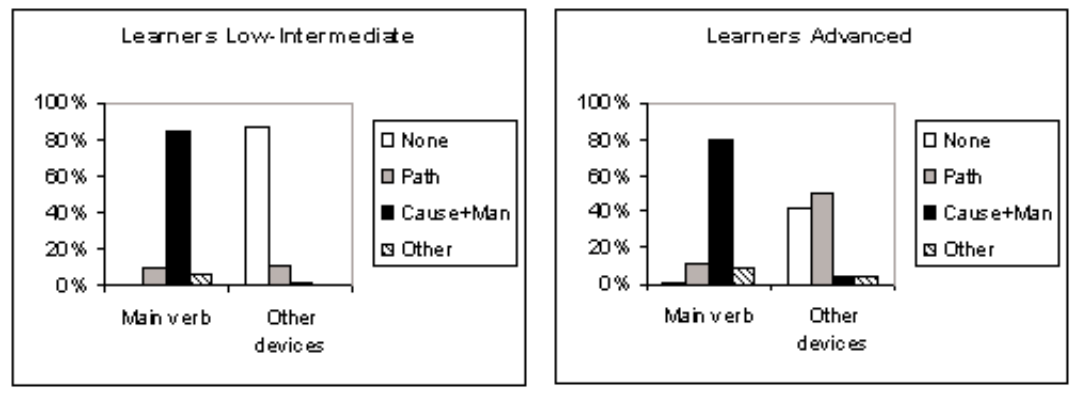

However, depending on proficiency level, they used different strategies with respect to PATH. Low-intermediate learners either 1) used expressions that did not necessarily imply a location change (15) or 2) expressed PATH in a second independent main clause (16) in a construction that was grammatically felicitous (despite the invented lexical item ascendre 'to ascend') but clearly not most typical of French and that resulted in an overall lower utterance density in 
this group. In contrast to native speakers, no variation in response patterns occurred across item types.

(15) Papy pousser/poussé une roue dans une caverné dans les bois. (LOW-INT_01)

'Popi to push/pushed a tire in a cave in the woods.'

(16) Popi tirer/tiré une sac et \# et ascende le \# le toit. (LOW-INT_01)

'He to pull/pulled a bag and \# and ascends the \# the roof.'

More advanced learners resorted to other solutions. They produced some idiosyncratic expressions that transformed French PATH verbs into satellite-like devices. For example, entre (17) and au travers (18) are existing French prepositions ('between' and 'through') but the former is also a form of the verb entrer 'to enter' and the latter does not clearly express boundary crossing in this context.

(17) Il rouler/roulé le roue dans \# entre le ferme. (ADV_06)

* 'He to roll/rolled the tire in \# between/enter the shed.'

(18) Donc il pousse le panier de pommes au travers la \# la route de \# dans le village. (ADV 03)

* 'So he pushes the basket of apples across/through the \# the road of \# in the village.'

Advanced learners also produced some complex structures containing subordinate PATH verbs (19), showing that they seemed to have caught onto the fact that French frequently expresses PATH in verb-like devices.

(19) $[\ldots]$ et il le tire après lui en traversant la rue. (ADV_03)

' $[\ldots]$ and he pulls it behind him crossing the road.'

Although French native speakers do resort to such structures, they mostly express PATH in main verbs and CAUSE+MANNER in subordinate structures, as in (20). As a result, neither option is target-like.

(20) Il monte la dune de sable en tirant la petite voiture. (F06)

'He goes up the sand dune pulling the little car.'

\section{Discussion}

\subsection{Summary of findings}

This study compared how different groups of adult speakers (English learners of French at low-intermediate $v s$. advanced levels of proficiency, native 
speakers of English or French) described caused motion events in a controlled experimental situation where they were shown animated cartoons involving multiple types of information that could not all be easily expressed together. The major aim was to examine the processes whereby learners map the semantic components of caused motion events onto L2 surface forms and how their developing system evolves with proficiency. Particular attention was placed on determining whether the typological properties of the source and target languages (satellite - vs. verb-framed) had an impact on this process. Three sets of related analyses examined how speakers selected, encoded, and organized information in their responses, focusing on 1) the overall semantic density of their responses (number of components expressed), 2) the particular types of information expressed (CAUSE, MANNER OF CAUSE AND MANNER OF MOTION, PATH), and 3) the particular devices used to express this information (main verb vs. other devices).

The analyses concerning overall semantic density showed that the responses produced by learners were less dense than native speakers' reponses, irrespective of proficiency level (low-intermediate, advanced) and of the native speakers' language (English, French). Nonetheless, a strong increase in density occurred across learners' groups, showing an increasing capacity to encode multiple types of information from lower to more advanced proficiency levels. A language difference was also found among native speakers, whose responses were somewhat denser in English than in French. This difference was expected on the basis of the typological properties of English $v s$. French, since it was predicted that English would allow a more compact packaging of spatial information than French. However, this language effect was not as marked as was expected among native speakers, perhaps because the task invited subjects to produce much information at once and therefore to use some complex structures they may not have produced in more natural speech situations. This situation, then, may have resulted in artificially dense utterances, particularly in French, where less dense utterances were expected. In this respect, our previous results concerning voluntary motion did show a strong language difference in density ( $c f$. Section 1), suggesting the need for further crosslinguistic research across a variety of situations.

Analyses also examined which semantic components were expressed: CAUSE (causal relation between A and O); MANNER (manner of cause or of O's displacement); PATH (of A and O). Native speakers expressed all three types of information in both languages, despite a somewhat greater tendency to do so in English as compared to French. In contrast, although learners frequently expressed CAUSE+MANNER, they did not systematically express PATH, particularly 
in the low-intermediate group. This result seems surprising since PATH is most basic to motion events and might therefore be expected to be encoded before other types of information. One possible explanation may lie in the fact that the task could have focused learners' attention on causality (relation between the agent and the displaced object). However, some other aspects of the data also account for this finding.

As they are confronted with the target system during second language acquisition, learners must acquire relatively complex structures, including various types of subordination, in order to be able to encode multiple types of information. It is the ability to use such complex structures that allows the more advanced learners to provide semantically denser utterances as compared to low-intermediate learners. Thus, lower-level learners tend to express PATH separately from MANNER and CAUSE (in independent or coordinated clauses), whereas more advanced learners are able to integrate MANNER and CAUSE (in the main verb) with PATH in one of two ways : they use either target-like devices (such as verbs in subordinate clauses) or idiosyncratic non-target-like devices, such as particle-like devices that do not carry PATH information as such in the target language, e.g. locative prepositions to mark PATH (such as à travers 'across') or devices that could be either verbs or prepositions (such as entre 'into/to enter'). Low-level learners, then, do express PATH, but they do so in separate clauses, rather than in denser utterances that combine more varied informational components.

More detailed analyses concerning information locus showed strong differences between English vs. French natives that shed further light on these results. In particular, English speakers systematically encoded CAUSE+MANNER in main verbs and PATH in satellites. In contrast, a great variety of responses occurred among French speakers, whereby PATH, CAUSE and MANNER occurred in all parts of speech (main verbs $v s$. other devices, including subordinated verbs). In addition, more variation was observed in French verbs across item types. In this respect, further research is necessary to account for the special status of INTO items in French responses. In general, however, a major finding of this study is the striking contrast in information locus among native speakers. This finding was quite surprising, particularly in the degree to which it opposed a relatively systematic response pattern (English) to a highly variable pattern (French). One obvious implication of this finding is that English learners of French are faced with a target system that is rather opaque in comparison to their source system in the sense that it provides them with varied options to express the same content. In the absence of clear and sufficiently frequent 
negative evidence, French invites them to learn a large range of possible structures and acquiring such a system may therefore take some time and/or may result in transfer for a long time. This property of the French system may account particularly for the differences that were found between learners $v s$. native speakers, as well as for those that were found among learners across the two proficiency levels.

\subsection{Determinants of spatial language during second language acquisition}

Let us now consider the process whereby learners map semantic information about motion onto L2 surface forms during second language acquisition. We focus below on two questions in this respect. First, do typological properties of source and target languages influence this process in any way or do learners construct their own linguistic system independently of such constraints ? Our results show that both source (English) and target (French) languages influence how learners express caused motion. When expressing caused motion, learners initially apply the principles of organization that govern their first language onto their second language. In particular, their productions show a transfer of information locus from English onto French, which causes problems during the online production process. Thus, they follow the highly systematic English pattern, expressing CAUSE+MANNER in the main verb, but are then faced with the further problem of expressing PATH. They solve this problem in one of several ways : they either express PATH in separate clauses that are not integrated with the preceding information about CAUSE and MANNER; or they express PATH in a number of idiosyncratic ways, including by means of devices that cannot function as PATH markers in French. As we saw, French provides a rather variable input that allows for many possible patterns (but not for all), including 1) PATH in main verbs, as well as juxtaposed or coordinated clauses and 2) partially English-like structures, such as coding MANNER+CAUSE in the main verb (but no PATH particles). In comparison to their L1, then, French provides rather opaque evidence to the learner to discover the properties of the target language. Further research comparing our data with productions from native speakers and learners of other languages is necessary to determine whether the impact of typological constraints in second language acquisition can be generalized in a larger cross-linguistic perspective.

The second question concerns the development of the learners' system : How does the learners' system evolve from a lower level of proficiency to a more advanced proficiency level during acquisition? Comparisons between 
low-intermediate and advanced learners show one major change that involves the acquisition of subordination. Subordination is one way to solve the problem of expressing PATH with CAUSE and MANNER in French L2. Once learners have expressed MANNER +CAUSE in a verb, the acquisition of gerund-like subordinate clauses allows them to simply add PATH information within a complex structure that provides a fuller and more integrated response. As a result, responses become closer to native-like responses with respect to grammatical form. Nonetheless, although the responses of advanced learners are grammatically "correct", they still do not look native-like for several reasons : they rarely place PATH in the main verb, systematically reserving the coding of MANNER+CAUSE in the main verb (rather than in subordinate clauses where it frequently occurs in French).

Finally, it should be noted that several indices in the data reflect more general difficulties encountered by learners during the task, particularly by those who were at the lower level of proficiency. Learners' responses at this level displayed many "traces" (errors, searches, self-corrections, pauses) that show that the task was complex for them, especially because it required them to express multiple types of information simultaneously. These indices reflect linguistic processes that are not yet automatized in learners' speech in very different domains of their L2 developing system (gender, number, lexical choices, grammatical structures, etc.). Such traces, as well as the lower semantic density of their utterances, go well beyond the expression of caused motion per se and indicate difficulties that are not (or not necessarily) related to the particular typological properties of their source and target languages, which were of central interest in this study. However, in addition to such general processes during L2 acquisition, the focus and locus of spatial information in their speech both clearly show the impact of typological constraints which depend on lexicalization and grammaticalization patterns determining how information is selected and organized across satellite-framed vs. verb-framed languages in this domain.

\subsection{Conceptualizing space during first and second language acquisition}

A final question concerns the cognitive implications of typological constraints during first and second language acquisition. Some current crosslinguistic research proposes that typological determinants of language acquisition may have a deep impact on children's cognitive organization beyond language use per se, influencing how they construct spatial categories and organize their conceptual representations. With respect to second language 
acquisition, a most challenging question concerns the extent to which the focus/locus of spatial information in given source/target languages may invite learners to re-organize their conceptual representation of space.

The present study provided subjects (visually) with a large number of information components, inviting them to be as complete as possible in their responses, and it therefore may not have been entirely 'ecological'. Nonetheless, the capacity to perceive these dimensions and to construct a complete cognitive representation presents no particular problem to (mature) adult learners. The real problem for them is to find native-like means of simultaneously expressing much information, some of which are relatively complex and not available to them, particularly at the low-intermediate proficiency level. Once they have acquired these means, the question is whether they then actually re-organize their underlying representations in order to fit the most prototypical L2 pattern. The present data do not allow us to answer this question. In particular, further research using complementary measures is necessary to determine the nature of subjects' underlying representations beyond language use. In addition, more proficiency levels must be examined in order to determine the extent to which learners may or may not reach 'final' native-like ways of organizing information in their L2.

This said, the main results concerning our native data, as well as a further inspection of these data, show several differences between French and English that may provide partial evidence towards answering this question. First, whereas English native speakers typically produced responses that were simple and compact ( $c f$. examples (10) or (12) above), French speakers' descriptions of the target events had the following properties, particularly when they attempted to be fully explicit : in addition to an occasional reliance on independent or coordinated clauses ( $c f$. (14b) above), dense responses implied rather complex French structures (21a), and they contained frequent hesitations and reformulations (21b). Second, native speakers differed strikingly with respect to how they organized discourse more generally. In addition to their reliance on varied structures to describe target events, French speakers typically produced longer and more detailed responses than English speakers, for example, showing a particular concern with initial setting information in utterances that surrounded their target response.

(21) a. [...] donc on a Popi qui est en bas de la dune de sable à gauche du paysage, donc la colline se situe plutôt vers la droite, donc il est avec cette bouée qu'il pousse en la faisant rouler de manière à la faire monter sur la dune de sable. (F09) 'So we have Popi that is at the bottom of the sand dune at the left of the 
landscape, so the hill is situated rather to the right, so he is with this swimming ring which he pushes by making it roll in such as way as to make it ascend on the sand dune.'

b. $[\ldots]$ on a donc Popi qui se trouve à gauche de la rue et qui tire un landau pour traverser - qui fait traverser le landau - donc qui fait traverser la rue donc en tirant le landau $[. .$.$] et donc il atteint le trottoir à droite. (F09)$

'So we have Popi who is at the left of the street and who pulls a pram in order to cross - who makes cross the pram - so who makes cross the road so by pulling the pram $[\ldots]$ and so he reaches the opposite sidewalk.'

Such patterns are in line with studies of other V-framed languages in first language acquisition (e.g., Berman \& Slobin, 1993). They are also consistent with results reported about second language acquisition in relation to other referential domains (cf. von Stutterheim \& Lambert, 2005 about temporality). They suggest that typological factors may constrain not only how speakers construe particular events in their native language, but also how they organize discourse more globally, leading to some resistance during second language acquisition.

\subsection{Implications for teaching during second language acquisition}

Notwithstanding open questions, and assuming that future research will allow us to generalize our conclusions to other discourse situations and to other languages, the results have some implications for teaching during second language acquisition. They first suggest that the type of knowledge underlying the capacity to express caused motion events - and more generally spatial information - in a second language is strongly influenced by learners' native systems. Once acquired during first language acquisition, their native system provides a prototypical "window" onto events which is quite resistant to change, even requiring some cognitive restructuring in discourse.

Second, our experimental situation invited learners to use complex structures for the complete expression of events in order to combine several types of information compactly. Such situations may be useful in triggering the acquisition of complex structures in discourse, pointing to the need to go beyond simple sentences for an efficient packaging of information. Furthermore, in line with other studies, our results show the importance of teaching native-like discourse strategies that go beyond grammatical knowledge at the sentence level. Although discourse structuring is now frequently integrated into classroom teaching for first language acquisition, it is still insufficiently introduced in second language teaching. Various findings in second language 
acquisition research all converge to show that we need to understand why discourse produced by second language learners frequently remains non-nativelike, even during very late phases of acquisition when they are able to produce sentences that are entirely grammatical. Further research in the classroom is clearly necessary to determine whether and how students can be made to master the different discourse principles operating across languages.

\section{APPENDIX}

\section{Summary of main features in the stimuli*}

\begin{tabular}{|l|l|l|l|l|l|}
\hline $\begin{array}{l}\text { Combination } \\
\text { \& exemplars }\end{array}$ & $\begin{array}{l}\text { Ground } \\
\text { referent }\end{array}$ & $\begin{array}{l}\text { PATH OF } \\
\text { MOTION }\end{array}$ & $\begin{array}{l}\text { MANNER } \\
\text { OF CAUSE }\end{array}$ & $\begin{array}{l}\text { Figure } \\
\text { object }\end{array}$ & $\begin{array}{l}\text { MANNER OF } \\
\text { O-MOTION }\end{array}$ \\
\hline $1 \mathrm{a}-\mathrm{b}$ & roof or sand dune & up & push & swimming ring & roll \\
\hline $2 \mathrm{a}-\mathrm{b}$ & & & & package & slide \\
\hline $3 \mathrm{a}-\mathrm{b}$ & & & pull & toy car & roll \\
\hline $4 \mathrm{a}-\mathrm{b}$ & & & & bag & slide \\
\hline $5 \mathrm{a}-\mathrm{b}$ & snow or grass hill & down & push & balloon & roll \\
\hline $6 \mathrm{a}-\mathrm{b}$ & & & & suitcase & slide \\
\hline $7 \mathrm{a}-\mathrm{b}$ & & & pull & wheelbarrow & roll \\
\hline $8 \mathrm{a}-\mathrm{b}$ & & & & trunk & slide \\
\hline $9 \mathrm{a}-\mathrm{b}$ & road or street & across & push & wheel & roll \\
\hline $10 \mathrm{a}-\mathrm{b}$ & & & & apple basket & slide \\
\hline $11 \mathrm{a}-\mathrm{b}$ & & & pull & pram & roll \\
\hline $12 \mathrm{a}-\mathrm{b}$ & & & & rocking horse & slide \\
\hline $13 \mathrm{a}-\mathrm{b}$ & cave or barn & into & push & tire & roll \\
\hline $14 \mathrm{a}-\mathrm{b}$ & & & & table & slide \\
\hline $15 \mathrm{a}-\mathrm{b}$ & & & pull & shopping trolley & roll \\
\hline $16 \mathrm{a}-\mathrm{b}$ & & & & chair & slide \\
\hline
\end{tabular}

"Subjects saw two exemplars (a-b) of each combination, both of which showed the same figure object but with a different scenery and ground object. РАTH was always the same for the agent $\mathrm{A}$ and for the object $\mathrm{O}$. The two remaining information components presented (variables A and B) were held constant in all 32 test items: CAUSE (causal relation between $\mathrm{A}$ and $\mathrm{O}$ ) and MANNER OF A-MOTION (walking). 


\section{REFERENCES}

ASKE, J. 1989. Path predicates in English and Spanish: a closer look. In: Proceedings of the Berkeley Linguistics Society n ${ }^{\circ}$ 15, 1-14.

BECKER, A. \& M. CARROLL 1997. The Acquisition of Spatial Relations in a Second Language. Amsterdam, Philadelphia, John Benjamins.

BERMAN, R. \& D. SLOBIN 1993. Relating Events in Narrative: a Crosslinguistic Developmental Study. New York: Lawrence Erlbaum Associates.

BOWERMAN, M. 1996. The origins of children's spatial semantic categories: cognitive versus linguistic determinants. In J.J. Gumperz \& S.C. Levinson (eds.), Rethinking Linguistic Relativity, 145-176. Cambridge, Cambridge University Press.

BOWERMAN, M. \& S. CHOI 2003. Space under construction: language-specific categorization in first language acquisition. In D. Gentner \& S. Goldin-Meadow (eds.), Language in Mind: Advances in the study of language and thought, 387427. Cambridge, MA, MIT Press.

BROWN, P. 2001. Learning to talk about motion UP and DOWN in Tzeltal: Is there a language-specific bias for verb learning? In M. Bowerman \& S.C. Levinson (eds.), Language Acquisition and Conceptual Development, 512-543. Cambridge, Cambridge University Press.

CADIERNO, T. 2004. Expressing motion events in a second language: a cognitive typological perspective. In M. Achard \& S. Niemeier (eds.), Cognitive Linguistics, Second Language Acquisition, and Foreign Language Teaching, 1349. Berlin, New York, Mouton de Gruyter.

CADIERNO, T. \& K. LUND 2004. Cognitive linguistics and second language acquisition: motion events in a typological framework. In B. VanPatten, J. Williams, S. Rott, \& M. Overstreet (eds.), Form-meaning Connections in Second Language Acquisition, 139-154. Mahwah, New Jersey, Lawrence Erlbaum Associates.

CARROLL, M., J. MURCIA-SERRA, M. WATOREK \& A. BENDISCOLI 2000. The relevance of information organization to second language acquisition studies: The descriptive discourse of advanced learners of German. Studies in Second Language Acquisition $\mathrm{n}^{\circ}$ 22, 3, 441-466.

CARROLL, M., A. ROSSDEUTSCHER, M. LAMBERT \& C. von STUTTERHEIM 2008. Subordination in narratives and macro-structual planning: a comparative point of view. In C. Fabricius-Hansen, C. Ramm \& W. Ramm (eds.), 'Subordination'versus 'coordination' in sentence and text, 161-184. Amsterdam, John Benjamins.

CARROLL, M. \& Ch. von STUTTERHEIM 2003. Typology and information organization: perspective-taking and language-specific effects in the construal of events. In A. Giacalone-Ramat (ed.), Typology and second language acquisition, 365-402. Berlin, Mouton de Gruyter. 
CHOI, S. \& M. BOWERMAN 1991. Learning to express motion events in English and Korean: the influence of language-specific lexicalization patterns. Cognition, $\mathrm{n}^{\circ}$ 41, 83-121.

CLARK, E. 2003. Language and representations. In D. Gentner \& S. Goldin-Meadow (eds.), Language in Mind: Advances in the study of language and thought, 1724. Cambridge, MA: MIT Press.

GENTNER, D. \& S. GOLDIN-MEADOW (eds.) 2003. Language in Mind: Advances in the study of language and thought. Cambridge, MA, MIT Press

GUMPERZ, J. J. \& S. C. LEVINSON 1996. Rethinking Linguistic Relativity. Cambridge, Cambridge University Press.

HENDRIKS, H. 2005. Structuring space in discourse. A comparison of Chinese, French, German and English L1 and French, German and English L2 acquisition. In H. Hendriks (ed.) The Structure of Learner Varieties, 111-156. Berlin, Mouton de Gruyter.

HICKMANN, M. 2003. Children's Discourse: Person, space and time across languages. Cambridge, Cambridge University Press.

HICKMANN, M. 2007. Static and dynamic location in French: Developmental and crosslinguistic perspectives. In M. Aurnague, M. Hickmann \& L. Vieu (eds.), Spatial Entities in Language and Cognition, 205-231. Amsterdam, John Benjamins.

HICKMANN, M. \& H. HENDRIKS 2005. Children's expression of caused motion in French and English. Paper presented at the IASCL conference, July: Berlin, Germany.

HICKMANN, M. \& H. Hendriks 2006. Static and dynamic location in French and in English. First Language $\mathrm{n}^{\circ}$ 26,1, 103-135.

HICKMANN, M. \& S. ROBERT (eds.) 2006. Space across Languages: Linguistic systems and cognitive categories. Amsterdam, John Benjamins.

LANDAU, B. \& L. LAKUSTA 2006. Spatial language and spatial representation: autonomy and interaction. In M. Hickmann \& S. Robert (eds.), Space in languages: linguistic systems and cognitive categories (pp. 309-333). Amsterdam/Philadelphia: John Benjamins.

LEVINSON, S.C. \& D. WILKINS 2006. Space in Language and Cognition: Explorations in cognitive diversity. Cambridge, Cambridge University Press.

MANDLER, J. M. 1998. Representation. In W. Damon, D. Kuhn \& R. S. Siegler (eds.), Handbook of Child Psychology, Vol. 2, 255-308. New York: Wiley.

MUNNICH, E. \& B. LANDAU 2003. The effects of spatial language on spatial representation: setting some boundaries. In D. Gentner \& S. Goldin-Meadow (eds.), Language in Mind : Advances in the study of language and thought, 113155. Cambridge, MA: MIT Press.

NUYTS, J. \& E. PEDERSON (eds) 1997. Language and conceptualization. Cambridge: Cambridge University Press. 
SLOBIN, D. I. 1996. From 'thought to language' to 'thinking for speaking'. In J. J. Gumperz \& S.C. Levinson (eds.), Rethinking Linguistic Relativity, 70-96. Cambridge, Cambridge University Press.

SLOBIN, D.I. 1997. Mind, code and text. In J. Bybee, J. Haiman \& S.A. Thompson (eds.), Essays on Language Function and Language Type: Dedicated to T. Givón, 438-467. Amsterdam, Benjamins.

SLOBIN, D.I. 2003. Language and thought online: cognitive consequences of linguistic relativity. In D. Gentner \& S. Goldin-Meadow (eds.), Language in Mind: Advances in the study of language and thought, 157-191. Cambridge, MA, MIT Press.

SLOBIN, D.I. 2003. The many ways to search for a frog. In S. Strömqvist \& L. Verhoeven (eds.), Relating Events in Narrative: Typological and contextual perspectives, 219-257. Hillsdale, NJ, Erlbaum.

SLOBIN, D.I. 2006. What makes manner of motion salient? Explorations in linguistic typology, discourse, and cognition. In M. Hickmann \& S. Robert (eds.), Space across Languages: Linguistic systems and cognitive categories, 59-81. Amsterdam, John Benjamins.

SPELKE, E. S. 1998. Nativism, empiricism, and the origins of knowledge. Infant Behavior \& Development $\mathrm{n}^{\circ} 21,181-200$.

STRÖMQVIST, S. \& L. VERHOEVEN (eds.) 2003. Relating Events in Narrative: Typological and contextual perspective. Hillsdale, NJ, Erlbaum.

Von STUTTERHEIM, Ch. 2003. Linguistic structure and information organization: the case of very advanced learners. In S. Foster-Cohen \& S. Pekarek Doehler (eds.), EUROSLA Yearbook, 183-206. Amsterdam, John Benjamins.

Von STUTTERHEIM, Ch. \& M. LAMBERT 2005. Cross-linguistic analyses of temporal perspectives in text production. In H. Hendriks (eds.), The structure of learner varieties, 203-230. Berlin, Mouton de Gruyter.

TALMY, L. 1983. How language structures space. In H. Pick \& L. Acredolo (eds.) Spatial Orientation: Theory, research and application, 225-282. New York, London, Plenum Press.

TALMY, L. 1985. Lexicalization patterns: semantic structure in lexical forms. In T. Shopen, S. Anderson, T. Givon, R. Keenan, \& S. Thompson (eds.) Language Typology and Syntactic Fieldwork, vol. 3, 57-149. New York, Cambridge University Press.

TALMY, L. 2000. Towards a Cognitive Semantics. Harvard, MIT Press. 


\section{RÉSUMÉ}

Cette étude examine l'impact des propriétés typologiques des langues (à satellites ou à cadrage verbal) sur l'expression du mouvement provoqué au cours de l'acquisition des langues secondes par l'adulte. Le corpus comprend des productions recueillies au moyen de supports animés auprès de 24 locuteurs anglophones apprenant le français à deux niveaux de compétence (12 débutantsmoyens, 12 avancés) et de 24 locuteurs natifs (12 anglophones, 12 francophones). Les natifs diffèrent quant à la densité sémantique de leurs réponses (anglais $>$ français) et ils utilisent des moyens systématiques (anglais) ou variables (français) pour exprimer l'information. Quant aux apprenants, la densité sémantique de leurs réponses augmente avec leur niveau de compétence grâce à l'apprentissage de nouvelles structures complexes. Ces locuteurs tentent de produire des structures cibles, qui restent néanmoins conformes à la langue source aux deux niveaux de compétence, montrant l'impact des langues L1/L2. Ces contraintes typologiques indiquent que les apprenants ne construisent pas un système linguistique entièrement indépendant au cours de l'acquisition et que leur maîtrise de la L2 pourrait passer par une re-conceptualisation de l'information spatiale. De nouvelles directions de recherche sont nécessaires afin d'explorer les implications de ces résultats pour l'enseignement des langues. (Mots-clés : acquisition des langues secondes, typologie, espace, mouvement provoqué.) 